\title{
Barriers to the implementation of primary prevention of risky behaviour in school in the context of teacher/ school prevention methodologist activities
}

\author{
Miroslav Procházka \\ University of South Bohemia in České Budějovice, Faculty of Education
}

Received 15. 8. 2020 / final version received 1. 2. 2021 / accepted 9. 3.2021

\begin{abstract}
This research article is related to the issue of risky behaviour of elementary and high school pupils from the point of view of teachers responsible for implementing school-based primary prevention programs. The author aims at the perspective of teachers who serve as school prevention methodologists and who organize, realize, and assess school prevention programs. The text describes discursive questions related to prevention and the potential of the teachers leading to the effective implementation of school-based prevention programs. The presented research outcomes show the teachers' evaluation of conditions provided for the realization of prevention programs in schools; it then analyses interviews with the teachers about behaviour issues they encounter in their students.
\end{abstract}

Risky behaviour prevention is an obligatory component of education in the Czech Republic. Schools create prevention strategies and programs as part of the school curriculum. The key questions related to creating these documents include clarifying the general topics that the school should address within the theoretical bases, defining the key priorities and specifying the main topics in the prevention program. School prevention methodologists have a lack of confidence, which prevents them from preparing and evaluating the programs properly. Teachers must contend with a number of issues, yet they are not certain enough about the effective conditions and processes needed for the successful realization of prevention programs.

The first part of the research design is based on data obtained from the mind maps analysis. These mind maps are the outcome of the school prevention methodologists' participation in focus groups $(n=28)$. Within these groups, participants captured the issues and conditions related to their personal view of the realization of prevention programs in their schools. The subsequent content analysis of the text, according to Klapko (2013), provides an interesting use of the connection between the primary overall mapping of the issue of the distribution of variables using a selected categorical key and the in-depth data analysis within the context of the qualitative research study. The analysis of mind maps was realized in accordance with the research method 
described by Gavora (2010): the basic set of texts was determined (in this particular case, the mind maps), then the semantic units were classified into several analytic categories, and these units were finally quantified and described. The interpretation of the results (by the technique of "laying cards on the table") is based on the research data obtained during the second phase of the research. This part concerns the interviews with teachers about their mind maps. The participants were asked to explain their personal attitude reflected in the selection of given categories and in the formulation of the logic chains. Research outcomes show important knowledge related to the realization of prevention programs in 28 schools in the South Bohemia region, all of which require support in this respect.

Keywords: primary prevention, risky behaviour, elementary school, school prevention methodologist

Primary prevention is a very broad topic that encompasses a number of current and sensitive areas. Current Czech legislation imposes the obligation on schools, in relation to pupils, to "create conditions for their healthy development and to prevent the emergence of socially pathological phenomena" (Act No. 561/2004 Coll., § 29 [1]). After a series of contradictory steps and often non-conceptual decisions that accompanied the implementation of such prevention in schools, the responsibility for implementation was de facto transferred to the schools themselves; this was done by creating a specialized pedagogical position: School prevention methodologist. The aim of this study is to describe selected aspects of the implementation of prevention in school conditions, and to examine this issue in connection with the activities of the school prevention methodologist. In the research study, the aim is to uncover what barriers the prevention methodologists perceive that inhibit the execution of their activities. We assume that the methodological and advisory activities of these members of the teaching staff will require a supportive and collegial approach on both the horizontal and vertical levels. Even though school prevention methodologists are perceived as specialized pedagogical personnel, their normal teaching duties are in no way eliminated. Identifying the barriers and the difficulties that these teachers have to overcome in practice may indicate the areas in which their managerial and mentoring support should be directed. 


\section{Selected aspects of the implementation of prevention in school}

The current strategy of primary prevention declared by the Ministry of Education, Youth, and Sports of the Czech Republic (hereinafter MŠMT) for the years 2019-2027 (MŠMT, 2019) avers an important change in the education paradigm. In accordance with foreign knowledge (e.g. Gallà, et al., 2005; Otto \& Thiersch, et al., 2005; Telka et al., 2003), students, and their competences and development needs are becoming the key target area. The accentuated change of the prevention strategy is a very important moment and starting point for development of the school prevention programs and is aligned with conceptual changes in the Czech education system (Čech, 2011). These embodied changes, for example, in the concept of the educational strategy until 2030 (MŠMT, 2020), accentuate the development of key competencies needed for proactive civil and professional life. Prevention is implemented within learning triangles defined, on one part, by the school and its program and environment, on the second part, by the teacher and their competencies and responsibilities, and on the third part, by the students and their development aspects, needs, and difficulties.

In relation to the school, primary prevention is based on the general curricular documents, i.e. at the national level in the Czech Republic in the so-called Framework Educational Programme developed into a model of primary and secondary education (MŠMT, 2017). At the school level, prevention is included in the school curriculum (e.g. Miovský et al., 2015b,c). The conceptual framework of prevention is associated with the development of the so-called school prevention strategy and the minimum prevention program of each school (Miovský et al., 2015a; Miovský et al., 2012). School prevention is therefore currently included in the goals and objectives of the school education to respond to the importance of a competency-based approach (e.g. Exnerová et al., 2012). The basis for the implementation of this approach is a committed teacher facing the task of being available, helpful, and advising, activating, and supervising (Bakic et al., 2008). Teachers, together with parents, are the witnesses of the child's development, accompanying them during their most sensitive periods in schooling. In terms of the present research, in which teacher respondents described their work with students in the higher primary and secondary school (age category from about 11 to 18 years), the key for discursive consideration of school prevention is to have a look at the tasks of this development stage. 
Pubescence and adolescence together are a period of accelerated and dynamic physical, cognitive, emotional, and social development (Steinberg, 2010). During this transition period, the student is exposed to pressures that often lead to an increased suicide rate and various forms of psychopathology (Wong et al., 2011); risky behaviours are developed such as alcohol and drug abuse (Chen et al., 2009), trouble with the law, or leaning towards extremist thoughts and beliefs (Ecarius et al., 2011). The opinion of Piaget and Inhelder (1997) who notice the continuity of development stages and suggest the possibility of transferring problems from one period of life to another is inspiring in understanding the situation. The situation is described by Erikson's view of the conflict between child and adult identity, and the internal conflict between rejected childhood and yet immature and insecure adolescence. Erikson (2002) emphasizes the ethical dimension of this transformation in which the learned child spirit is to reach the ethics of an adult. In this respect, the author also introduces the context of risky behaviour. He describes how crucial it is for an adolescent to rely, in his search, on their experience and certainty based on self-knowledge. Preventing risky behaviour has the potential for personal and social development of the student and the formation of their life skills and self-knowledge.

The key to the child's development in adolescence is an environment where they come into contact with their peers and face other adult authorities. Many authors have studied the connection of the social environment and more general characteristics of behaviour (positive or social risky) having regard to various aspects of this influence (Krech et al., 1962). In the context of this paper, the inspiration comes from Helus (2007) who studied the problems of the socialization process of children and youth and also addressed the sociopsychological moments of the influence of the environment on personality. Pelikán $(1997,2002)$ long studied the importance of school education and the relationship between education and the environment. His accent on the role of the life situation in education as well as the relationship between education, person, and the social group is especially important. Šafárová (2002) put the occurrence of risky behaviour in a broader context of negative trends in society. Dzierzbicka (2008) refers to risky behaviour in the context of the crisis of discipline in Foucault's disintegration of disciplinary society. Deleuze (1993) describes the pressure mechanisms of social control which, in a society of permanent training and retraining, lead to the individual dependence on taking tests as proof of them being good and sufficient. 
Štech (2015) presents an interesting context of prevention in relation to the socialization influences of the school environment. The author emphasizes the importance of the school as a wider social world. In this world, the appropriate educational (and therefore preventive) acts can make visible, explicitly named, and shown in public such conditions and situations in which children and youth involved in education begin to perceive and understand the meaning of all words such as rules, forgiveness, empathy, compassion, responsibility, fellowship, and cooperation. The school receives a large and socially important role. Consequently, those whose work is most involved in this kind of educational act become very important.

\section{School prevention programs}

Minimum prevention programs are currently a mandatory part of the primary and secondary school curriculum. Preventive educational activities should then become an integral part of teaching and school life. The program's efficiency highly depends on how it is integrated into the daily school life (Čech, 2011). Only this way can we assist children in the long period of schooling to gradually acquire the key competencies and mindsets and the core values of a healthy lifestyle. Therefore, it is necessary for prevention to become a natural part of the educational work of all teachers and other teaching staff of the school and to be comprehensible to students' parents as well. It must not become an "extra" program outside the main course of the school's educational work.

The aim of the school prevention is to comprehensively change the patterns of behaviour. Therefore, the purpose is not to implement random activities. It is also not about ad hoc response to individual signs of risky behaviour, but the aim is to achieve an overall change in the school climate. Prevention may therefore include the following teacher activities to support (MŠMT, 2001):

- the development of students' healthy lifestyle;

- the development of students' ability to cope with their free time in a positive way;

- an increase of the social competence of students (for example, activities and approaches leading to the development of social skills that help children establish themselves in social relationships and understand their responsibility for behaviour and actions related to themselves and others); 
- a strengthening of students' communication skills (teaching students how to solve specific problems and conflicts, teaching them to bear criticism, apply assertive behaviour, not suffer from stress, and cope with their emotions);

- in promoting a positive social climate in the school and classroom (building trust in the classroom, teaching students to work with other peers in the group); and

- the formation of students' attitudes to socially accepted values (cultivating democratic habits, humanistic attitudes, morals and moral values).

We mention the above-cited document because, for the first time, it clearly specifies the activities that should be a priority for schools. The aforementioned target areas were defined to construct the minimum prevention programs in an effort to set up an educational framework for building the preventive protective competence of students at the beginning of the 21st century (MŠMT, 2001). In connection with a change of the primary and secondary school curriculum, prevention is discussed in topics that describe the areas for the development of competencies and creation of life skills (Miovský et al., 2015c).

The current national prevention strategy (MŠMT, 2019) respects the division of activities and programs into "specific" (focused on specific risk manifestations of behaviour), and "non-specific". Schools have a wide range of opportunities within this area to support a healthy lifestyle, initiate positive social behaviour, activate the use of leisure time, and to develop the pupil's personality in relation to himself and to others.

Risky behaviour is the key term on which to focus prevention activities at school (Dolejš, 2010; Macek, 1999; Miovský et al., 2015a; MŠMT, 2010). This term replaced the previously used key term of socially pathological phenomenon. The discursive shift makes it possible to stop thinking about how to prevent the impact of pathological phenomena of "social nature" on teaching and rather focuses educational activities on the student and their behaviour in the social context. The relationship between the individual and a social group, the life of the individual in a school class, and the social climate of the school class is becoming the key point. The importance of clarifying the individual group standards comes into play again. An important goal of prevention will be to strengthen the desirable ideas and values and the effort to denormalise the beliefs that spread through the group, e.g. relative 
to so-called legal drugs and their frequency in the population (Miovský et al., 2015a).

\section{Teacher activities - prevention methods}

The educational aspect is an important internal condition for the effectiveness of school prevention. In this context, Štech (2015) refers to the educational act which brings into prevention the internalization of a situation experience that has come close to, or exceeded, the risk threshold. Therefore, the important basis for prevention is to achieve a state where real educational situations are used for educational activities at school. These can be both staged preventive activities and solutions to a real challenge in the classroom. Only this way will prevention succeed in delivering the necessary educational impact.

This means that the implementation of a prevention program in school will depend on the attitude and erudition of teachers and their ability to use difficult situations in school for the goals and objectives in education and prevention. However, monitoring the readiness of teachers to solve educationally challenging situations at school showed that teachers feel very insecure in this respect (Vítečková, 2018; Vítečková \& Gadušová, 2015; Vítečková et al., 2016a,b). According to the TALIS 2018 study (ČŠI, 2020), Czech teachers are very sceptical about their competencies in the field of education; it can then be concluded that the ability to take advantage of discipline problems and conflicts with children in the educational and preventive sense will be difficult.

The effective implementation of school prevention is to be helped by the creation of a specialized position of a school prevention methodologist. This is an appointed school employee, usually a teacher who has completed compulsory qualification studies of 250 hours in lifelong learning courses. The standard activities of a school prevention methodologist are defined in Decree No. 72/2005 Coll., on the provision of counselling services in schools and school guidance facilities, as amended (MŠMT, 2005). The decree classifies three types of obligations:

- methodological (guidance) and coordination activities;

- information activities;

- consulting activities. 
The current definition of the position of a school prevention methodologist is defined by the National Strategy for Primary Prevention of Risky Behaviour of Children and Youth for the Period 2019-2027 (MŠMT, 2019). The strategic document provides a list of activities where the concepts of coordination, participation, and methodological guidance dominate. The list of a wide range of essentially mentoring and managerial activities attributed to one of the school teachers shows the challenges of this function and high expectations associated with this special work. When analysing the above list, however, it should be noted that most of it involves coordination tasks. Therefore, such a trained teacher is expected to be able to create and lead (coordinate) relationships inside and outside the school. They will then use their competencies acquired through specialized studies not only to pursue the specified activities, but also to promote personal and social attitudes towards students to influence the positive social climate at school.

\section{Research Objectives and Research Questions}

The general aim of the study is to examine the issue of barriers to the implementation of school prevention in connection with the activities of the prevention methodologist. With a view to the responsibility of the school prevention methodologist for the coordination and implementation of the school's prevention program, it is important to map those teachers' view of the obstacles and barriers to prevention in the school. The coordination basis of the methodological activities will be analysed based on the opinions regarding the quality of the school prevention methodologist's relationship with other key partners in the school. Prevention is understood as specific teaching and educational activities both specifically focused on the prevention of risky behaviour and non-specific activities devoted to the development of personal or social competencies of students. The conditions for the implementation of a prevention program are understood as procedural and personnel circumstances that provide the basis for real chances to promote prevention in school. The educational situation in our research is represented by the situation in which the teacher plays the educational role in relation to the students. Cooperation is understood as relationships created by the teacher appointed for prevention counselling with their colleagues or experts who, as external co-workers, participate in the implementation of a school prevention program. 
Based on the aforementioned main goal of the research, specific research questions were formulated. We set out with an interest to answer the following research question: What are the challenges and barriers to the implementation of a prevention program in school? We then want to record the circumstances perceived by school prevention methodologists as obstacles to their work; how they can be specified, and what their characteristics are in relation to the personnel, material, and program conditions of the school and the role of the methodologist as a prevention coordinator. We also want to determine: What specific obstacles to the implementation of a prevention program are identified by prevention methodologists at school? Our assumption is that school prevention methodologists, as members of the school counselling centre, are invited to address a number of educational situations. To this end, they would start to work together with other partners in and out of school. We want to identify how they feel about the conditions for this work, and how they evaluate the background provided by the school in this respect. The research interest in the activities of the methodology of prevention, and in the definition of research questions, are related to a broader research plan that involves monitoring the functioning of the school in the conditions of inclusion.

\section{Research Design}

The nature of research questions that are open-ended and based on general concepts rather than specific variables (Šed'ová, 2007) offers the use of qualitative research. The source of data is on the one hand, written materials in the form of mind maps and written documents in which the participants recorded the concepts they associated with challenges during the implementation of a prevention program. Other sources are provided by the analysis of data obtained from interviews with informants / school prevention methodologists.

\subsection{Data Collection Technique}

The data collection took place in two stages. A survey was conducted in the first stage using the created conceptual data, while interviews took place in the second stage. The defined research problem: "What general topics are considered by prevention methodologists as challenges and barriers in their work?" was reflected in a specific instruction to create a mind map 
that was subsequently analysed. Participants were informed as follows: "Create an individual mind map in which you record the barriers and challenges you face during implementation of a prevention program at your school." Following individual work, the resulting data was used for further discussion in the group. The additional instruction was: "Divide into groups and discuss together the topics you have recorded in your mind maps." For the assignment, the graphical representation was emphasized in which "prevention challenges and barriers" is placed in the middle of the mind map, and the importance of each topic depends on the distance from the centre.

As mentioned above, the method of the mind (mental) map was chosen for the research survey. The reason for this was that the graphic processing of opinions is non-traditional and, in most cases, unknown to the informants. Furthermore, this method was used because this technique is excellent for the nonlinear recording of keywords and for capturing the motives and links between them, as described by Buzan (2007). The consequent content analysis of the text, as Klapko (2013) states, allows for an interesting possibility of connecting the initial mass mapping of the topic represented by variables according to a categorical key, and then conducting an in-depth data analysis of a qualitative research study. The procedure mentioned by Gavora (2010) was followed in the analysis of mind maps: at first, the basic set of texts was defined (in our case, mind maps) to identify semantic units that were consequently classified into analytical categories, quantified, and described. The interpretation of results (using the technique of "laying cards") (Šed'ová, 2007), is also based on the subsequent interview and discussion of each mind map. In the interview, the informants explained their points of view reflected in the choice of categories and in the formulation of logical chains.

The task was given to participants of the lifelong learning course, namely the basic qualification study program for school prevention methodologists (group of novice methodologists) and the extension optional course for experienced methodologists (the second group of participants). The research was conducted after the course introduction, when the content was presented to participants. Each participant was instructed to capture the areas, in their opinion and based on their experience, where they see barriers to the successful implementation of a school prevention program. It was also specified that challenges or barriers are understood to be specific phenomena and challenges that they face during the implementation of a prevention program at their school that prevents achieving the prevention 
goals and objectives. In the introduction, the principles of the mind map were recounted and explained to participants. After they created their individual mind maps, each person presented the result of their work in the group and clarified or explained their results in a controlled interview with the author, the instructor of the course. Based on the categories recorded in the individual mind maps, questions were formulated for the subsequent interview. Presentations and interviews and the responses of informants in the interview were recorded with a video camera and consequently used to supplement the data collected from mind maps.

The research set was established on the basis of intentional selection, with two sets of informants created. The first group included 14 informants, experienced prevention methodologists who had completed a specialized study and further expanded their knowledge in the lifelong learning course. The average length of experience in school prevention programs was six years. The second group consisted of 14 informants who were also participants in the compulsory course for school prevention methodologists, so their compulsory education was not completed. The average length of experience in school prevention programs was two years. There were 28 mind maps created and used in research.

\section{Results}

In view of the fact that we analysed mind maps consisting of keyword records, those were semantic units that were subsequently quantified and classified into categories. The basic keywords emerged from the individual mind maps of school prevention methodologists and were graphically connected directly with the term prevention challenges and barriers (located in the middle of the mind map). These keywords were further subcategorized. All the above keywords pointing to the central term were then processed to define the common parent categories and graphically displayed as shown in Figure 1. The size of the subcategory boxes reflects the frequency of the phenomenon captured in partial mind maps. 


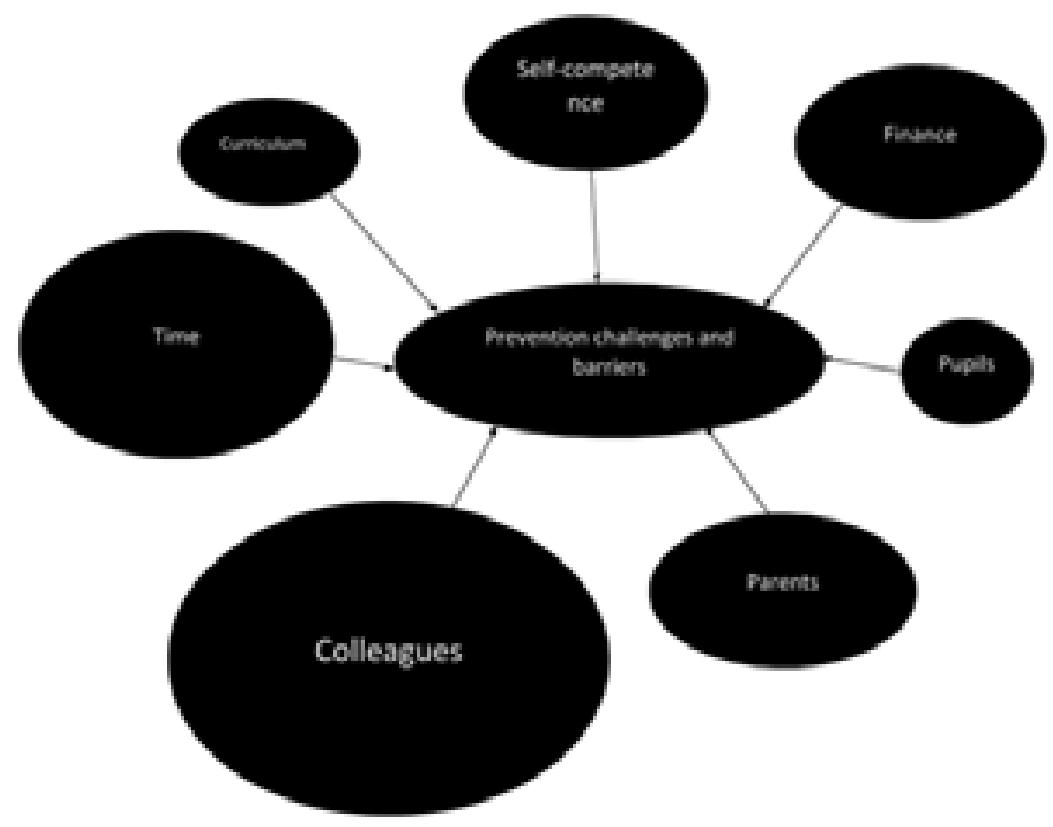

Figure 1. Major areas pointing to the concept of "prevention challenges and barriers" (the size of each picture indicates the frequency of use).

Figure 1 shows the most frequent statements in mind maps combined into the following categories: Colleagues, Time, Parents, Self-competence, Finance, Curriculum, and Students. In the mind maps, each statement was elaborated using a broader phrase (e.g. lack of cooperation and bad example in the category of Parents) or additional sub-terms in the category (e.g. subcategories such as they do not believe, they do not understand, they are not interested were identified in the Parents category). A summary table was created using Microsoft Excel when further analysing the statements to concentrate the individual terms and additional statements. The semantic order was determined by the number of statements in each category. 
The Colleagues category was included in 27 maps, and it was identified as a dominant challenge. This category was associated with a number of subcategories. According to methodologists, the barrier lies in a negative attitude, reluctance, lack of interest, disagreement, or even repeatedly resistance. But the phenomenon of cooperation is the key issue regarding the coordination basis of the activities. Participants used the mind mapping tool repeatedly to extend their feelings into broader statements, and the supportive approach in the teaching staff became the leading topic of subsequent interviews. Part of the problem is the generally negative approach to the preventive and educational component of the teacher's work. For example, the informant feels that "not every teacher in our school is willing to attend to their class". We can see the opinion that resistant teachers are those who either "do not want extra work", "do not want to spend time on further preparation", or they only focus on teaching their subject: "colleagues resistant to doing anything else but teaching". According to our research, the approach of another group of teachers to prevention is clearly negative. For example, the informant stated: "it is just a marginal issue for many teachers, they do not believe in the idea of it - they feel it is about nothing anyway". The research also identified the still-prevailing low level of teamwork and isolation in the teaching staff. Participants described the inconsistency between lower and higher primary school teachers. However, most of the statements showed the general reluctance to work as a team and share information with each other. The disunity is seen in the context of lack of "management support", but also in the reluctance to "discuss things with others, share information, pretending they do not have any problems". The research indicates that some teachers tend to not solve difficult things or keep them only for themselves.

The Time category appeared in 24 maps as the second most important challenge in the implementation of a prevention program. Following a further analysis, the statements were semantically divided into two subcategories. The first can be described as subjective lack of time for the school prevention methodologist's work. Informants pointed out their "high number of teaching hours", and they feel a "collision with the function of a class teacher" with an increasing administration. For example, one informant put it this way: "I am a teacher; when I am supposed to do a preventive activity for other classes, I lack the 'free' hours to do it." The second dimension of the perceived time barrier can, to some extent, be referred to as objective. It is 
the time in the overall school curriculum. The participating methodologists feel that "the school schedule is tight, or there are many events in the school, teaching gets slowly out of play". This category is logically connected to a specific Curriculum category. In nine cases, informants commented on the lack of interfaces between the school curriculum and prevention. School work is characterized as the "implementation of the educational program in school" and prevention as "release from class". The informant said the program includes "other school priorities", or the program reflects a "wellestablished system that works". Prevention is then something that is not part of the school's program, but always "at the expense of something else". One opinion is that you should primarily teach lessons in school, and according to another participant, there is "little time in school for activities that promote cooperation" between students.

The categories of Parents, Finance, and Self-competence were mentioned in 19 cases. Cooperation with parents was used to reflect on the more general relationships between school and family as well as the specific perception of prevention by parents. At the first level, statements described the family's general lack of interest in educational issues. For example, the informant provided statements describing the parents' attitude that "the school must take care of everything for us", or hyper-protective parents were mentioned who consider risky behaviour to be something that "does not have to do with their child". The participating prevention methodologists pointed out that parents do not understand prevention. It is partly because "there is no opportunity to tell them 'why' and what the benefits are", parents then "do not believe, do not understand, or play it down".

The Finance category was closely linked to the Parents category. The recorded statements confirmed the reality of the Czech school where educational programs implemented by external instructors are not covered by the school's current budget. Teachers have to collect course fees from students, so they are co-financed by the students' parents. Therefore, the experience of prevention methodologists is logically related to the above point as the parents are reluctant to "participate in the payment". However, the informants also admit that good quality programs are expensive, for example, because their school is "difficult to access", it is a "village school with a low budget, or a small school with few students". The culprits identified by the methodologists are the "education authorities", but in four cases also the school principals. 
The category of Prevention Methodologist and Their Competencies had different relationships in the set of data obtained from experienced prevention methodologists (eight statements) and from novice methodologists (11 statements). The experienced prevention methodologists would rather choose categories referring to objective circumstances and obstacles, e.g. the conflict between the role of teacher and the role of methodologist, the interference with the duties of the class teacher, or the bad conditions for work resulting from the non-reduced number of teaching hours, but also to their own limitations such as "procrastination", "lack of knowledge of activities", "failure to evaluate the effectiveness of activities", or "their own abilities". The group of novice methodologists had a tendency to comment on this area more often, with dominant feelings that could be summarized in categories: little respect in the teaching staff, lack of experience - sharing materials, lack of good practice databases and underestimation of the prevention methodologist's work. In four cases, the prevention methodologists also mentioned the lack of back office. It was also interesting to follow the recorded problems associated with students. The Student category was mentioned in five cases by experienced prevention methodologists and only once by novice methodologists with a rather positive connotation, where the prevention methodologist mentioned the lack of opportunities for greater contact with children.

The keywords shown in Figure 1 directly related to the concept of prevention challenges and barriers being further broken down. A detailed analysis of each mind map showed some interconnection of the categories. The problem of the prevention methodologist's relationship with other teachers is also linked to communication with parents. These are known to the teacher - prevention methodologist primarily as related to the class they teach, while their other contacts are strongly dependent on others. The Curriculum category is also connected with the phenomenon of cooperation in school. If the prevention program is not included in the school curriculum, it becomes a burden to other teachers, thus losing its connection with the teaching activities of other teachers. At the same time, the conditions set up for a teacher-prevention methodologist will depend on finances, time, and the school environment as an organisation. The last broader category is the own perception of the prevention methodologist, their sense of readiness for this role, and the respect and authority they enjoy in this position, i.e. self-reflection. In this context, more general categories were created from all the semantic units listed in the mind maps. They are summarized in Table 1 below. 


\section{Table 1}

\section{Created Analytical Categories and Related Keywords}

\begin{tabular}{|c|c|c|}
\hline \multirow[t]{3}{*}{ Cooperation } & Colleagues & $\begin{array}{l}\text { Available time, approach, little interest, inconsistency, } \\
\text { reluctance, lack of interest, colleagues' attitude, disagreement } \\
\text { with the program, resistance of some colleagues, they do } \\
\text { not want extra work, non-unification, they do not believe } \\
\text { in the idea, lack of support, substitution, inconsistency, not } \\
\text { sharing information, reluctant to discuss things with others, } \\
\text { unwillingness to cooperate }\end{array}$ \\
\hline & Parents & $\begin{array}{l}\text { Disagreement of parents, attitude of some parents, lack of } \\
\text { support from parents, bad example in the family, lack of family } \\
\text { interest, inadequate assumptions, they do not believe, they } \\
\text { do not understand, they do not have time, playing it down, } \\
\text { misunderstanding, there is no opportunity }\end{array}$ \\
\hline & Curriculum & $\begin{array}{l}\text { Thematic planning, little time for activities, fulfilment of the } \\
\text { educational program, lessons must be taught, at the expense } \\
\text { of hours, limited number of hours, many other events, time } \\
\text { schedule, busy program, other school priorities }\end{array}$ \\
\hline \multirow[t]{3}{*}{ Organisation } & Time & $\begin{array}{l}\text { Teaching hours, administration, little time, collision, available } \\
\text { time, limits, inconsistent timetables }\end{array}$ \\
\hline & Finance & $\begin{array}{l}\text { No school funds, financial hardship of parents, poor social } \\
\text { level of parents, expensive programs, unwillingness to } \\
\text { participate in payment, principal, pay, educational authorities, } \\
\text { small school, few students, financial limits }\end{array}$ \\
\hline & Environment & $\begin{array}{l}\text { Space, facilities, place for an individual interview, classroom } \\
\text { equipment, separate office }\end{array}$ \\
\hline \multirow[t]{3}{*}{ Self-reflection } & Knowledge & $\begin{array}{l}\text { I didn't graduate in "this", sharing materials, lack of knowledge } \\
\text { of activities, lack of know-how }\end{array}$ \\
\hline & Experience & $\begin{array}{l}\text { Good practice database, program offer, procrastination, lack } \\
\text { of abilities, competence, low self-esteem, stress, fatigue }\end{array}$ \\
\hline & Respect & $\begin{array}{l}\text { Underestimation of the methodologist's work, little respect } \\
\text { in the staff }\end{array}$ \\
\hline
\end{tabular}

\section{Discussion and Conclusion}

In the research, we examined the implementation of school prevention programs in the context of the prevention methodologist's work. This specially qualified teacher is responsible for the overall prevention process at school. We identified that their role primarily consists of coordination, guidance, and support, or information background of the implementation 
of a prevention program. It should be part of the educational program at school and consequently incorporated in the overall educational strategy of the school. The definitions of the national strategic documents mentioned above are put in practice through the engagement of the teacher trained in methodology. Therefore, the key for us was to identify the obstacles and barriers as perceived by those teachers at work.

Three groups of challenges were identified by the analysis of mind maps. The coordination and methodological role of this teacher proved to be crucial. Participants consider the cooperation with colleagues as a fundamental problem. They meet some members of the school teaching team who refuse to participate in educational and preventive activities. Some of them are described by the participants as teachers who consider teaching their subjects as the core of their educational work and other activities as an undesirable disruption of this process. This opinion corresponds with research that suggests a role conflict of teachers. For example, Havlík and Kota (2007) speak about internal conflicts in which the fulfilment of one role disrupts the management of requirements arising from the other role. In the postmodern era, the psychological challenges associated with the transfer of knowledge to students interfere with the requirements for the ethical and educational component of school education. Research describes the feelings of future, beginning, and experienced teachers (e.g., Vítečková, 2018; Hanušová et al., 2017) showing a negative experience of the situation faced in school in connection with the growing resistance of students to the dominant forms of education still applied in practice (Kartous, 2019; Feřtek, 2015) and the related explosion of educational problems. New phenomena are created that are very difficult for teachers to understand. As a result, there is a growing number of experienced teachers showing burnout symptoms as well as a high dropout rate of beginning teachers (Vítečková, 2018; Hanušová et al., 2017), or a declining interest in teaching studies or becoming a teacher in practice after graduation (Pravdová, 2014). One of the reasons is that teachers are worried about failing to cope with the specific requirements of working with children newly included in class groups as part of the inclusion project and the related educational, teaching, and disciplinary problems.

Our research shows that while a team of teachers should come together to focus on the development of students' key competences and promote a positive classroom climate, a part of it remains in opposition. In this respect, 
the informants mentioned the disunity of teachers, low management support and the reluctance of teachers to share information with others and discuss problems in "their" classroom with colleagues. These findings are in line with the climate characteristics of teaching staff by Urbánek's current research (2005). However, we identified the problem does not only have relational root causes but is also related to the orientation of the primary school curriculum. In a situation where the need for school orientation to transfer values and develop skills (Spilková et al., 2004) and to develop students' competencies towards cooperation (Kasíková, 2010) are ever more emphasized, the barrier to these efforts lies in some teachers who aim at teaching their subject in the first place.

The methodological and coordinating role of the prevention methodologist further includes ensuring that parents are informed and that cooperation with them has been initiated. In this regard, research findings confirmed that school and teachers are continuously uncertain about working with parents. The research identified an opinion of prevention methodologists regarding the ever more difficult communication with families from different social and cultural backgrounds, perceived as families that do not cooperate and set a bad example where there is nothing to build on. At the same time, some statements underlined the overall discrepancy between school expectations and the parents' opinions or requirements similar to what is suggested by Rabušicová et al. (2004), Šed'ová (2009), Majerčíková (2015), and others.

In terms of organisational conditions for the implementation of prevention programs, the participants mainly referred to time pressure. This is in some way related to the previous phenomenon. If the teacher - prevention methodologist remains isolated in the team, it will be very difficult to coordinate their normal teaching duties with another function. This tension was concisely mentioned by the informants when they explained the collision of duties between working with "their" class and activities for other students and other teachers. In this respect, they saw their situation as very difficult to manage. The results then largely uphold the experience with the negative effects of accumulated functions and responsibilities of teachers. Specifically in the field of prevention, foreign experience proves to be positive where an external expert who is responsible for prevention becomes a member of the school team. For example, in Slovakia, a social education worker has been included in the school team as an expert in preventive and social and educational work (Hroncová et al., 2020). Similar experience with the 
application of social work teachers in school prevention, educational work with children and youth from social risk environment, or communication with families from different social and cultural backgrounds can be found in schools in Hungary, Norway, Finland, and Spain. When applying the inclusive education approach and with regard to the increasing social, cultural, and economic diversity of children, a social work teacher in the Czech school can be a kind of imaginary bolt and provide full support for students, parents, and colleagues in the school counselling centre (Procházka, Paroubková, \& Šimerová, 2019). Another aspect of the organizational barriers identified by research is the lack of background for counselling and support activities. The informants mentioned that they miss a dedicated area where they could solve the students' problems and carry out their work in a discreet environment.

The last area perceived as a barrier to prevention was self-reflection on competencies. The participants explained they do not feel ready enough to implement a prevention program and deal with educational problems they encounter in this respect. Thus, the research findings showing that teacher's educational work is one of the biggest challenges and teachers feel they are not well trained and qualified in this area (Vítečková, 2018) were confirmed. Doubts about their own competencies also resonate with the underestimation of the prevention methodologist's work and little respect among the teaching staff. In this respect, we consider as relevant the perception of the corrosion of teachers' authority as such, and we tend toward the conclusions of Vališová et al. (1999) who give evidence of how a growing chaos in the social hierarchy, norms, and values hinders the possibility of maintaining consensus in school on mutual support-based behaviour.

The results of the qualitative research survey do not aspire to generalize the results; instead, they rather reflect the opinions of the teachers involved. Nevertheless, the research has opened several questions that suggest how complex the position of prevention methodologists actually is. Although they are team members of the school counselling centre and have a clearly defined role and responsibilities, they do not receive appropriate support. Where their role is crucial, i.e. coordination and methodology and guidance of prevention, they encounter insufficiently defined powers and underestimation of the educational and preventive role of the school. Compliance problems are growing, and students engage in risky behaviour. A school without discipline 
then becomes ineffective and dangerous for its staff (Bendl, 2011). In this situation, cooperation among teachers, and the focus of school educational programs on new development priorities, are very important.

\section{References}

Act No. 561/2004 Sb. Act No. 561/2004 Coll. on pre-school, primary, secondary, higher vocational and other education (School Act). (2004).

Bakic, J., Diebäcker, M., \& Hammer, E. (Eds.) (2008). Aktuelle Leitbegriffe der socialen Arbeit. Ein kritischen Handbuch. Wien: Erhard Löcker.

Buzan, T. (2007). Mentální mapování. Praha: Portál.

Chen C-Y, Storr C. L, \& Anthony J. C. (2009). Early-onset drug use and risk for drug dependence problems. Addictive behaviors, 34(3), 319-322.

Čech, T. (2011). Škola a její preventivně-výchovná strategie jako předpoklad rozvoje kompetencí dětí. Prevence, 8(7), 4-7.

ČŠI. (2020). Mezinárodní šetření TALIS 2018. Zkušenosti, názory a postoje učitelů a ředitelů škol. Národní zpráva. Praha: ČŠI, MŠMT.

Deleuze, G. (1993). Postskriptum über die Kontrollgesellschaften. In Unterhandlungen 1972-1990 (pp. 254-262). Frankfurt/M.: Suhrkamp.

Dolejš, M. (2010). Efektivní včasná diagnostika rizikového chování adolescentů. Olomouc: Univerzita Palackého v Olomouci, Filozofická fakulta.

Dzierzbicka, A. (2008). Prävention und Disziplinierung. In J. Bakic, M. Diebäcker, \& E. Hammer (Eds.), Aktuelle Leitbegriffe der socialen Arbeit. Ein kritischen Handbuch (pp. 170-184). Wien: Erhard Löcker.

Ecarius, J., Eulenbach, M., Fuchs, T., \& Walgenbach, K. (2011). Jugend und Sozialisation. Wiesbaden: VS Verlag für Sozialwissenschaften / Springer.

Erikson, E., H. (2002). Dětství a společnost. Praha: Argo.

Exnerová, M., Kaufová, T., \& Skácelová, L. (2012). Kočičí zahrada. Rozvoj sociálních dovedností dětí v rámci prevence rizikového chování. Praha: Univerzita Karlova v Praze \& Togga.

Feřtek, T. (2015). Co je nového ve vzdělávání. Praha: Nová Beseda.

Gallá, M., Aertsen, P., \& Daatland, C., DeSwert, J., Fenk, R., ... Sannen, A. (2005). Jak ve škole vytvořit zdravější prostředí: Př́ručka o efektivní školní drogové prevenci. Praha: Úřad vlády České republiky.

Gavora, P. (2010). Úvod do pedagogického výzkumu. Brno: Paido.

Hanušová, S., Píšová, M., Kohoutek, T., Minaříková, E., Janík, M., Janík, T., ... \& Ježek, S. (2017). Chtějí zůstat nebo odejít? Začínající učitelé v českých základních školách. Brno: Masarykova univerzita.

Havlík, R., \& Kotáa, J. (2007). Sociologie výchovy a školy. Praha: Portál.

Helus, Z. (2007). Sociální psychologie pro pedagogy. Praha: Grada.

Hroncová, J., Niklová, M., Hanesová, D., \& Dulovics, M. (2020). Sociálna pedagogika na Slovensku a v zahraničí - teoretická reflexia a prax. Banská Bystrica: Belianum, Univerzita Máteje Bela v Banské Bystrici.

Kartous, B. (2019). No Future. Praha: Nakladatelství 65. pole. 
Kasíková, H. (2010). Kooperativní učení, kooperativní škola. Praha: Portál.

Klapko, D. (2013). Obsahová analýza textu. In L. Gulová \& R. Šíp R. (Eds.), Výzkumné metody v pedagogické praxi (pp. 139-167). Praha: Grada.

Krech, D., Crutchfield, R. S., \& Ballachey, E. L. (1962). Individual in society: A textbook of social psychology. McGraw-Hill.

Macek, P. (1999). Adolescence. Psychologické a sociální charakteristiky dospívajících. Praha: Portál.

Majerčíková, J. (2015). Sporné aspekty úzkych vztahovov rodiny a školy na začiatku vzdelávania. Studia Paedagogica, 20(1), 29-44.

Miovský, M., Adámková, T., Barták, M., Čablová, L., Čech, T., ... Zapletalová, J. (2015a). Výkladový slovník základních pojmů školské prevence rizikového chování. Praha: Klinika adiktologie 1. LF UK a VFN v Praze v Nakladatelství Lidové noviny.

Miovský, M., Aujezká, A., Burešová, I., Čablová, L., Červenková, E., ... Žaloudíková, I. (2015b). Programy a intervence školské prevence rizikového chování v praxi ( $2^{\text {nd }} \mathrm{ed}$.). Praha: Klinika adiktologie 1. LF UK a VFN v Praze v Nakladatelství Lidové noviny.

Miovský, M., Skácelová, L., Zapletalová, J., Novák, P., Barták, M., ... Veselá, M. (2015c). Prevence rizikového chování ve školství. Praha: Klinika adiktologie 1. LF UK a VFN v Praze v Nakladatelství Lidové noviny.

Miovský, M., Skácelová, L., Čablová, L., Veselá, M., \& Zapletalová, J. (2012). Návrh doporučené struktury minimálního preventivního programu prevence rizikového chování pro základní školy. Praha: Univerzita Karlova v Praze \& Togga.

MŠMT. (2000). Strategie prevence společensky nežádoucích jevů u dětí a mládeže v působnosti resortu MŠMT na období 2001-2004. Praha: MŠMT.

MŠMT. (2001). Školní preventivní program pro mateřské a základní školy a školská zařízení. Praha: MŠMT.

MŠMT. (2005). Vyhláška č. 72/2005 Sb., o poskytování poradenských služeb ve školách a školských poradenských zařízeních.

MŠMT. (2010). Metodické doporučení k primární prevenci rizikového chování u dětí a mládeže. Dostupné z http://www.msmt.cz/vzdelavani/socialni-programy/metodicke-dokumentydoporuceni-a-pokyny.

MŠMT. (2017). Rámcový vzdělávací program pro základní školství. Praha: MŠMT.

MŠMT. (2019). Národní strategie primární prevence rizikového chování dětí a mládeže na období 2019-2027. Dostupné z http://www.msmt.cz/uploads/narodni_strategie_primarni_ prevence_2019_27.pdf

MŠMT. (2020). Hlavní směry vzdělávací politiky ČR do roku 2030. Dostupné z https: http://www. msmt.cz/vzdelavani/skolstvi-v-cr/strategie-2030

Otto, H.-U., \& Thiersch, H. (Eds.). (2005). Handbuch. Sozialarbeit. Sozialpädagogik. München: Ernst Reinhardt Verlag.

Pelikán, J. (1997). Výchova pro život. Praha: Nakladatelství ISV.

Pelikán, J. (2002). Pomáhat být. Praha: Karolinum.

Piaget, J., \& Inhelder, B. (1997). Psychologie dítěte. Praha: Portál.

Pravdová, B. (2014). Já jako učitel: profesní sebepojetí studenta učitelství. Brno: Masarykova univerzita. 
Procházka, M., Paroubková, A., \& Šimerová, K. (2019). Sociální pedagog. In M. Najmonová, K. Faltová, M. Garabiková-Pártlová, M. Faltová, J. Hynek, E. Nevoralová, R. Falta ..., \& M. Váchová, Školní poradenské pracoviště v praxi. České Budějovice: Pedagogická fakulta JU.

Spilková, V. et al. (2004). Současné proměny vzdělávání učitelů. Brno: Paido.

Steinberg, L. (2010). A behavioral scientist looks at the science of adolescent brain development. Brain and Cognition, 72(1), 160-164.

Šafářová, M. (2002). Rizikové chování v adolescenci. In V. Smékal \& P. Macek (Eds.), Utváření a vývoj osobnosti. Psychologické, sociální a pedagogické aspekty (pp. 191-208). Brno: Barrister \& Principal studio.

Šed’ová, K. (2007). Proces kvalitativního výzkumu a jeho plánování. In: Švaříček, R., \& Šed’ová, K., et al., Kvalitativní výzkum v pedagogických vědách (pp. 51-81). Praha: Portál.

Šed'ová, K. (2009). Tiché partnerství: vztahy mezi rodiči a učitelkami na prvním stupni základní školy. Studia Paedagogica, 14(1), 27-52.

Štech, S. (2015). Školní socializace, disciplinizace a prevence rizikového chování. In M. Miovský, L. Skácelová, J. Zapletalová, P. Novák, M. Barták, \& P. Bártík, P. et al., Prevence rizikového chování ve školství (pp. 145-152). Praha: Klinika adiktologie 1. LF UK a VFN v Praze v Nakladatelství Lidové noviny.

Rabušicová, M., Šed’ová, K., Trnková, K., \& Čiháček, V. (2004). Škola a (versus) rodina. Brno: Masarykova univerzita.

Telka, L. (Ed.). (2003). Programy profilaktyki uzależnień z doświadczeń autorow. Katowice: Biblioteha Pracownika Socialnego, Śląsk Wydawnictwo naukowe.

Urbánek, P. (2005). Vybrané problémy učitelské profese: Aktuální analýza. Liberec: Technická univerzita v Liberci, Fakulta pedagogická.

Vališová, A. (Ed.). (1999). Autorita ve výchově. Praha: Univerzita Karlova, Karolinum.

Vítečková, M., \& Gadušová, Z. (2015). Vysokoškolské studium učitelství z pohledu začínajícího učitele a identifikace jeho problematických oblastí. Edukácia, 1(1), 266-275.

Vítečková, M., Procházka, M., Gadušová, Z., \& Stranovská, E. (2016a). Identifying novice teacher needs - the basis for novices' targeted support. In G. Chova, L. Martínez, \& C. Torres, ICERI2016 Proceedings (pp. 7731-7738). Valencia: IATED Academy.

Vítečková, M., Procházka, M., Gadušová, Z., \& Stranovská, E. (2016b). Teacher at the start of his career and his personal needs. In M. Flégl, M. Houška, \& I. Krejčí (Eds.), Proceedings of the 13th international conference efficiency and responsibility in education (pp. 624-632). Praha: Czech University of Life Sciences Prague.

Vítečková, M. (2018). Začínající učitel: jeho potréeby a uvádění do profese. Brno: Paido.

Wong, M. M., Brower, K. J., \& Zucker, R. A. (2011). Sleep problems, suicidal ideation, and self-harm behaviors in adolescence. Journal of Psychiatric Research, 45(4), 505-511.

\section{Author}

PhDr. Miroslav Procházka, Ph.D., University of South Bohemia in České Budějovice,

Faculty of Education, Jeronýmova 10, 370 15, České Budějovice, e-mail: mproch@pf.jcu.cz 


\section{Překážky implementace primární prevence rizikového chování ve škole v kontextu činností metodika školní prevence}

Abstrakt: Výzkumný článek řeší problematiku rizikového chování žáků základních a středních škol z pohledu učitelů odpovědných za realizaci primární prevence ve školách. Autor se zaměřuje na reflexi učitelů, kteří zastávají pozici školního metodika prevence a kteří organizují, realizují a hodnotí školní preventivní programy. Text nejprve popisuje diskurzivní otázky týkající se koncepce prevence a komentuje potenciál učitelů, který je základem pro efektivní realizaci prevence ve školách. Prezentované výsledky výzkumu ukazují, jak učitelé hodnotí podmínky pro realizaci preventivních programů ve školách; poté analyzuje rozhovory s učiteli o problémech, se kterými se ve školách potýkají při výkonu svých povinností metodika. Prevence rizikového chování je v České republice povinnou součástí vzdělávání. Školy vytvářejí preventivní strategii a preventivní program, který je součástí školního vzdělávacího programu. Klíčovou otázkou související s tvorbou těchto školních dokumentů je vyjasnit, jakými výchovnými tématy by se měla škola zabývat, jaké si formuluje teoretické základy definující hlavní priority prevence a specifikující hlavní témata naplňující preventivní program. Ukazuje se, že metodici školní prevence nemají dostatečnou oporu v učitelském sboru, cožjim brání v adekvátní přípravě a hodnocení programů. Tito učitelé se musí vypořádat s řadou problémů, přesto si nejsou jisti, jaké jsou účinné podmínky a procesy potřebné pro úspěšnou realizaci preventivních programů. První etapa výzkumu je založena na datech získaných z analýzy myšlenkových map. Tyto mapy jsou výsledkem zapojení školních metodiků prevence v ohniskových skupinách $(\mathrm{n}=28)$. V rámci těchto skupin účastníci zachytili problémy a podmínky související s jejich osobním pohledem na realizaci preventivních programů na svých školách. Následná obsahová analýza textu podle Klapka (2013) poskytuje zajímavé využití spojení mezi primárním hromadným mapováním problematiky, distribucí proměnných díky následně stanovenému kategorickému klíči a hloubkovou analýzou dat v kontextu kvalitativní výzkumná studie. Analýza myšlenkových map byla provedena pomocí výzkumné metody popsané Gavorou (2010): byla stanovena základní sada textů ( $\mathrm{v}$ tomto konkrétním př́ípadě myšlenkové mapy), poté byly sémantické jednotky rozděleny do několika analytických kategorií a tyto jednotky byly nakonec kvantifikovány a popsány. Interpretace výsledků (technikou „vyložení karet") je založena na výzkumných datech získaných během druhé etapy výzkumu. Ta byla realizována sběrem dat formou rozhovorů s učiteli nad jejich myšlenkovými mapami. Participanti výzkumu byli požádáni, aby vysvětlili svůj osobní náhled na problémy ve škole odrážející se ve výběru daných kategorií a ve formulaci logických řetězců. Výsledky výzkumu přinášejí zajímavé informace související s realizací preventivních programů ve 28 školách v Jihočeském kraji, přičemž získaná data pojmenovávají bariéry bránící efektivní práci metodika prevence ve školách.

Klíčová slova: primární prevence, rizikové chování, základní škola, metodik školní prevence 